\title{
Perceptions about COVID-19 and their Myths and Belief: The Need to Provide Knowledge and Guidance to Public.
}

\author{
Tejas H.L. Kawre ${ }^{1}$, Dr.SwarupaChakole ${ }^{2}$ \\ ${ }^{1}$ Medical intern, Dept. Of Community Medicine, Jawaharlal Nehru Medical College, Datta Meghe Institute of \\ Medical Sciences, Wardha 442001. Maharashtra, India. \\ ${ }^{2}$ Professor, Dept of Community Medicine, Jawaharlal Nehru Medical College, Datta Meghe Institute of Medical \\ Sciences, Wardha 442001. \\ Email- tkawre@gmail.com \\ Review Article \\ Conflict of Interest: None
}

\begin{abstract}
Background: Efforts to promote COVID-19 will actually be in vain without a proper understanding of the perceptions and beliefs that prevail in society. That is why this study sought to identify the gaps in Ethiopia about COVID-19 false interpretation and lack of knowledge.

Methods: A survey was conducted online in Ethiopia from 22 April to 4 May 2020. The connection to the questionnaire were announced via email, digital media and the Jimma University website. The perception of COVID-19 was based on World Health Organisation (WHO) sources and knowledge. The Statistical Package for the Social Sciences (SPSS) version 20.0 software was used to analyse the data. A list of categories and factors was developed for facilitators' perceptions, barriers and information needs. An explanatory factor analysis (EFA) was conducted to support the categorization. Standardized category means were compared using analysis of variance (ANOVA) and t-test. The $\mathrm{p}<0.05$ value and significant differences were claimed as they were supposed to be taken as the very result of this article and further discussed in a manner of strategy to identify the false belief and superstitions regarding COVID-19.

Inference: The assumption that youth are at minimal chance of contracting COVID-19 requires continuous monitoring and attention. Communication chances and social participation activities need to take into account local and community variations in misbelief and fake assurances. Local efforts must be designed to meet source needs and increase community ownership of anti-viral measures, and should support efforts to address standard precautions. Various methods of communication must be used and appropriately understood to make out the misbelief and fake information.
\end{abstract}

Keywords: COVID-19, False belief, Survey, Myths.

\section{INTRODUCTION}

The latest coronavirus disease of 2019 (COVID-19 for short), announced by the World Health Organization (WHO) on 30 January 2020, is now a pandemic. [1]. In late December 2019, a cluster of pneumonia cases of unknown etiology was first reported in Wuhan, China, epidemiologically associated with exposure to seafood markets and undetected exposure [2, 3]. This disease that started as a sporadic infection in the city of china has now changed to a pandemic disease of the world wide scale and has led to many deaths and suffering in the countries along the global manifestation of the very rule bending position of crisis which has been a rule of history to repeat itself after a century.

The fight against COVID-19 continues in Ethiopia. Understanding the myths and perceptions is very important in order to eventually stop the virus. Some questions need to be answered. For sample, who can be assumed to be more prone to infection? What do communities think about the points promoting the viral spread? Do they think about things preventing the virus from spreading? How well is this perception understood by the scientific community? Are the facilitators and 
perceived barriers to the spread of the virus correctly or poorly understood? Do people take responsibility for combating the virus or do they act in spite of it? Solution to the problem's above are crucial for management of the spread as they increase the chances of community taking preventive measures .

WHO recommends risk communication and community involvement in research and control of "infodemic", misbelief and taint to effectively stop viral spread [2 $, 3,4]$. For example, the WHO reported in COVID-19 on risk perception, alcohol consumption, heat and antibiotic-related myths. In addition, up-to-date information on causes, protective measures, methods of transmission, confirmation and management procedures is required to battle misbeliefs and inference and to hold prevention $[5,6]$.

The need of COVID-19 for public health was recognised by the Ethiopian Government. Efforts have been made to decentralise detection, quarantine and treatment facilities and to promote preventive methods. By the time of investigation, it was declared an emergent state to provide preventive methods and took official steps such as closing institutes, and universities, introducing locally available preventive technologies such as washing hands in cooperation with public service points and limiting the number of people using public transport. The Ministry of Health has also addressed issues such as public awareness, risk communication and community participation and has called for voluntary action. For example, filling gaps in social beliefs, inference and knowledge can strengthen the termination of the virus. This article hence wanted to show the need for misbeliefs and awareness to public information in Ethiopia through a national online survey.

\section{METHODOLOGY AND RESOURCE}

\section{Study methods and steps}

A nationwide survey was performed in all of Ethiopia using the digital media. At the moment of the survey, Ethiopia was administratively classified into nine regions and two federal cities. The regions are divided into zones and districts, each with its own regional capital and zone/district cities. Network services are less available at the district level. According to the United Nations, population of Ethiopia in 2020 is approximated at 114,943,586. The population is $21.3 \%$ urban $(24,463,423$ in 2020). The average age in Ethiopia is 19.5 years [7]; the median literacy rate in Ethiopia in 2020 is $49.1 \%$ (adults $57.2 \%$ men, $41.1 \%$ women; adolescents): $71.1 \%$ men, $67.8 \%$ women). The questionnaire instrument was made using Google forms, and the link to the questionnaire were conducted via email communication, internet (digital/social media) and the website of Jimma University. The link of survey was shared on 22 April 2020 and 4 May 2020. By survey day collection of responses was done.

\section{Measurement and operationalization}

The instrument of truth and inference on the viral spread and its control has been mostly taken from WHO material. In addition, participants were free to give their opinion and interpretation about COVID-19. In general, asking about their perception of four themes. These were: perception of facilitating the spread of the virus ( 9 items), perception of preventing the spread of the virus ( 9 items), communication needs ( 7 items), chance labelling (8 items), provision of tools to communicate (7 items), and sociodemographic inconsistency, containing place of residence and community. The measurement of channels for communication was done on a scale from 1 to 7 , including ownership or 
control of media, official network, internet, medical professionals, communications, friends/neighbours and network services. Communities are defined as metropolitan cities and towns (regional and national capitals), cities at continental level and cities at continental level (semi-urban and rural). Observed trainers observed communities' perceptions of $\mathrm{p}$ COVID-19, and known preventers refer to communities false or true inference of points suppressing the virus. These known problems then subdivided in the following groups of points using explanatory factor analysis (EFA). A problem evaluation of 0.4 used for a cut-off mark to maintain products in different way. Kaiser Mayer Olkin's (SME $>50 \%$ ) pointed that it was enough to perform EFA.

\section{Data analysis}

The groups network replies were then coded in a tabulated database and then sent to SPSS version 20.0 to evaluate. The groups framework and beliefs were given in the frequency tables. Evaluated means (0-100) and main deviations were used to describe the list of factor categories, based on the perception theme to which they belong. Analysis and tests were calculated to differentiate by place, society and means of communication. Many replies were analysed and performed for perception; 95\% confidence intervals and p-values of 0.05 was made to claim a standard relationship. $[8,9,10]$

\section{RESULTS}

Population-based features of contributors Approximately 920 contributors of different of Ethiopia replied on the mass network survey. Table 1 shows the framework of the contributors. A majority of the contributors aged in range of 30-39 years $(50.8 \%)$, from Zonal towns $(56.0 \%)$, and the Oromia region $(56.6 \%)$.

Table 1Chosen population-based factors of contributors, May 2020, Ethiopia.

\begin{tabular}{|l|l|l|l|}
\hline Variables & Response category & Frequency & Percentage \\
\hline \multirow{5}{*}{ Age in years } & $18-29$ & 285 & 30.7 \\
\cline { 2 - 4 } & $30-39$ & 472 & 50.8 \\
\cline { 2 - 4 } & $>=40$ & 172 & 18.5 \\
\hline \multirow{4}{*}{ Religion } & Male & 828 & 89.1 \\
\cline { 2 - 4 } & Female & 101 & 10.9 \\
\hline \multirow{5}{*}{ Township } & Orthodox & 417 & 44.9 \\
\cline { 2 - 4 } & Protestant & 336 & 36.2 \\
\cline { 2 - 4 } & Muslim regional & 114 & 12.3 \\
\cline { 2 - 4 } & Others & 62 & 6.7 \\
\hline \multirow{5}{*}{ Region } & $\begin{array}{l}\text { Big } \\
\text { capitals/national) city }\end{array}$ & 520 & 34.3 \\
\cline { 2 - 4 } & Zonal level town & 520 & 56.0 \\
\cline { 2 - 4 } & $\begin{array}{l}\text { District level/Semi- } \\
\text { urban/town }\end{array}$ & 90 & 9.7 \\
\cline { 2 - 4 } & Oromia & 526 & 56.6 \\
\cline { 2 - 4 } & Addis Ababa & 139 & 15.0 \\
\cline { 2 - 4 } & SNNP* & 103 & 5.6 \\
\cline { 2 - 4 } & Amhara & 52 & 6.5 \\
\cline { 2 - 4 } & Tigrai & 60 & \\
\cline { 2 - 4 } & Other regions & & \\
\hline
\end{tabular}


*SNNP: Southern Nations and Nationalities People

Inferred contributing points: Peoples inference on communicability of COVID-19?

\section{Categorizations of factors}

Table 2 shows the factors and the list of drivers observed by COVID-19 dispersion, of its known perception. The results of the Explanatory Factor Analysis (EFA) revealed two main points of differentiation that were identified as motivating acceptance of COVID-19 in Ethiopia. The only point of differentiation is referred to as behavioural responses, suggestion of failure to take the anticipated defence measure to the spread of the virus. Factors contributing to behavioural compliance include continued shaking of hands, failure to seek medical attention for symptoms indicating COVID-19, use of pressure transport, failure to be seen for viral clinical feature and fright of taint, each with a load factor the score was in descending order (0.714-0.503). The other factor of alleged facilitators was inadequate in surroundings factors to back up the adaptation of preventive measures. The inadequacy of training conditions included the reluctance to stay at home for economic reasons, an overcrowded living and working environment and a lack of IPEs such as masks and disinfectants, with factor loading scores in descending order (0.786 to 0.718). Behavioural factors of non-compliance and lack of facilitation explain the general variation in the perception of facilitation of $48.8 \%$ of viruses.

Table 2Known factors and points differentiating COVID-19, May 2020, Ethiopia.

\begin{tabular}{|c|c|c|c|c|}
\hline \multirow{2}{*}{$\begin{array}{l}\text { Perceived } \\
\text { COVID-19 } \\
\text { exacerbating } \\
\text { factors }\end{array}$} & \multicolumn{2}{|c|}{$\begin{array}{l}\text { Principal components and factor } \\
\text { loading score }\end{array}$} & \multicolumn{2}{|c|}{ Descriptive statistics } \\
\hline & $\begin{array}{l}\text { Behavioral } \\
\text { non- adherence }\end{array}$ & $\begin{array}{l}\text { Lack of } \\
\text { enabling } \\
\text { environment }\end{array}$ & Freq. & $\%(95 \% \mathrm{CI})$ \\
\hline $\begin{array}{lr}\text { People } & \text { fear } \\
\text { stigma and bias } \\
\text { related } \\
\text { COVID-19 }\end{array}$ & .503 & & 584 & $62.9(59.7,65.9)$ \\
\hline $\begin{array}{l}\text { People still use } \\
\text { crowded } \\
\text { transportation } \\
\text { means }\end{array}$ & .654 & & 562 & $60.5(57.4,63.3)$ \\
\hline \begin{tabular}{lr}
\multicolumn{3}{l}{ People with flu- } \\
like symptoms \\
are not well \\
screened for \\
COVID-19 \\
\end{tabular} & .638 & & 551 & $59.3(56.1,62.5)$ \\
\hline $\begin{array}{l}\text { People don't } \\
\text { take prevention } \\
\text { for features that } \\
\text { are like COVID- } \\
19\end{array}$ & .681 & & 481 & $51.8(48.7,55.1)$ \\
\hline $\begin{array}{l}\text { People do hug } \\
\text { and shake hands } \\
\text { when greeting }\end{array}$ & .714 & & 416 & $44.8(41.5 .47 .8)$ \\
\hline $\begin{array}{l}\text { People don't } \\
\text { self-quarantine }\end{array}$ & & .786 & 858 & $92.4(90.6,94.2)$ \\
\hline
\end{tabular}




\begin{tabular}{|l|l|l|l|l|}
\hline $\begin{array}{l}\text { for economic } \\
\text { and social } \\
\text { reasons }\end{array}$ & & & & \\
\hline $\begin{array}{l}\text { People still live } \\
\text { and work in a } \\
\text { very crowded } \\
\text { condition }\end{array}$ & .705 & 814 & $87.6(85.4,89.6)$ \\
\hline $\begin{array}{l}\text { People do not } \\
\text { have face masks }\end{array}$ & .727 & 758 & $81.6(78.9,84.0)$ \\
\hline $\begin{array}{l}\text { People do not } \\
\text { have sanitizers }\end{array}$ & .718 & 735 & $79.1(76.3,81.6)$ \\
\hline
\end{tabular}

Notes: $\mathrm{KMO}=81.9 \%) ; \quad$ Variance Explained $(\mathrm{VE}=48.8 \%)$; and PPE: Personal Protective Equipment.

\section{Prevalence of facilitators}

The columns of descriptive statistics in Table 2 show the majority of selective features the category of factors to which they belong. The results show that the prevalence of specific factors contributing to behavioural independence ranged from $584(62.9 \%)$ to $416(44.8 \%)$. Terror of taint and prolonged use of the private car contributed to higher levels of disobedience. The level of lack of resources to support behavioural support ranged from $858(92.4 \%)$ to $735(79.1 \%)$. Inability to stay at home for financial reasons $(92.4 \%)$ and living and working in crowded places were the main reasons for the lack of "helpers". Adverse surrounding factors were observed more than behavioural infidelity, directing a higher factor to externalise points which exacerbate the spread of COVID-19 within the society. Fifty-three factors were reported as unknown $(5.7 \%, 95 \%$ CI: $4.3 \%-7.4 \%$ ).

Scattering of the perceptions: variables in regions and townships Zonal differentiation and variability The unilateral ANOVA revealed important zonal variation, mainly with regard to points inferred as inhibiting the communicability of the virus and the need for study. Mainly, the change was associated with misbelief $(\mathrm{F}=3.75, \mathrm{p}=$ $0.002)$, fake assurance $(\mathrm{F}=6.57, \mathrm{p}<$ $0.001)$, in general $(\mathrm{F}=2.48, \mathrm{p}=0.031)$, and the need for careful study $(\mathrm{F}=2.68, \mathrm{p}$ $=0.021)$. In addition, Figure 1 shows the mainly zonal concentrations of perceived virus spread and control. The results showed that the prevalence of myth was slightly, but significantly higher in Addis Ababa than in the Tigray and Oromia regions, where $\mathrm{MD}(95 \% \mathrm{CI})$ was 13.4 $(1.0,24.9 \%)$ and $9.1(1.3,16.9 \%)$, respectively. 


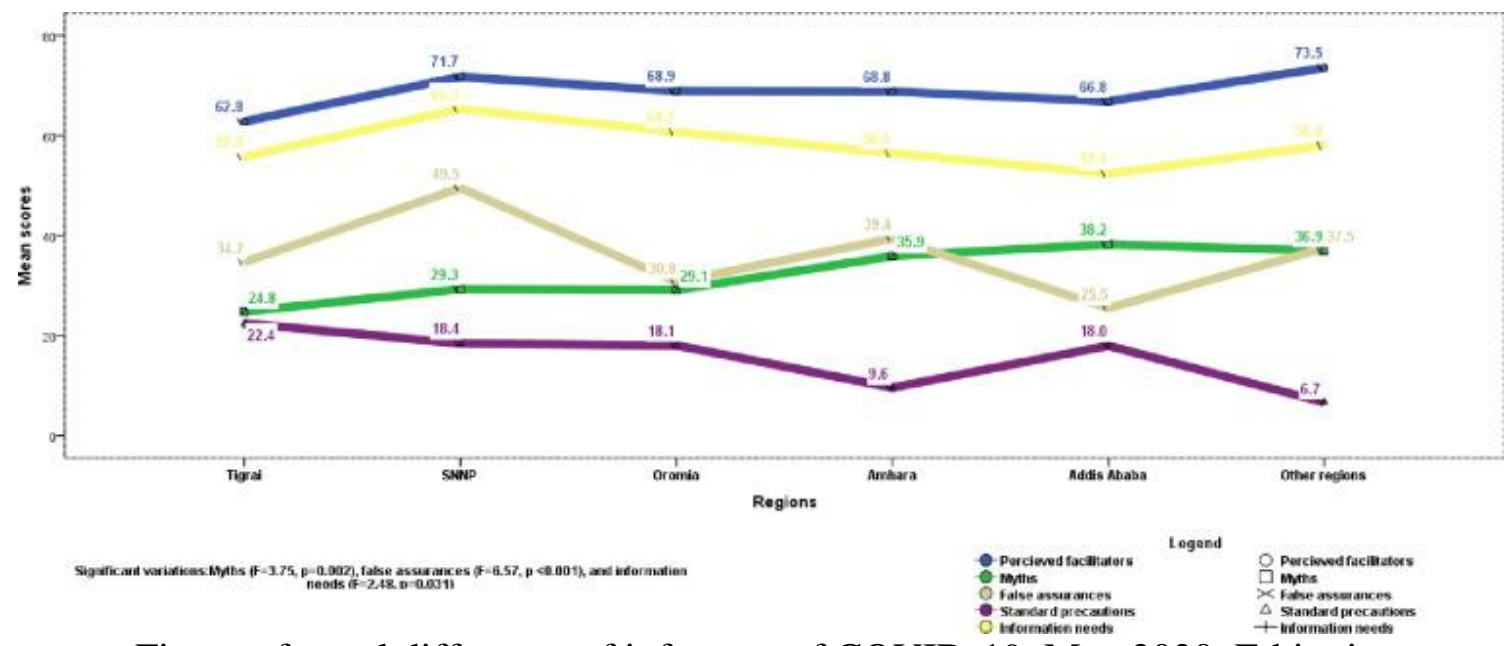

Figure of zonal difference of inference of COVID-19, May 2020, Ethiopia.

\section{Township distribution and variation}

While the communities studied presented many differences in misbelief $(\mathrm{F}=10.62$, $\mathrm{p}<0.001)$, general need for knowledge $(\mathrm{F}$ $=6.91, \mathrm{p}=0.001)$ and especially preventive study $(\mathrm{F}=5.23, \mathrm{p}=0.006)$, Figure 2 shows the schematic variation of community inference of the virus. For example, prevention misbelief in majority of metropolitan cities and districts, including Addis Ababa, than in zonal cities and district/semi-urban cities (MD $=9.4 \%$ (1.4-17.4\%), $\mathrm{p}=0.015)$. Communities living in districts and counties indicated a greater need for information in the community, especially about forms of protection, than those living in large cities and county towns, with MDs of $8.3 \%$ (1.2$15.4 \%, \mathrm{p}=0.015)$ and $16.4 \%(4.5-28.3 \%$, $\mathrm{p}=0.003$ ) respectively.

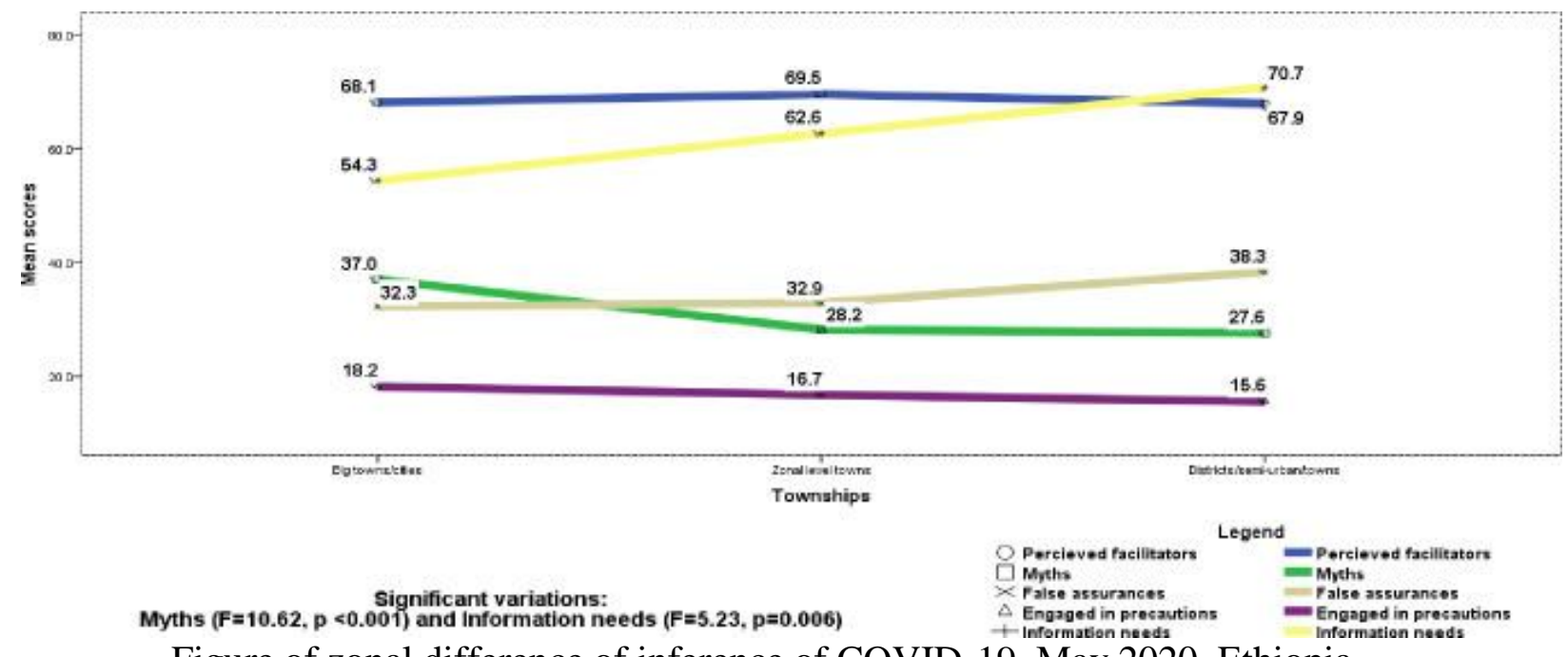

Figure of zonal difference of inference of COVID-19, May 2020, Ethiopia.

\section{RESULTS:}

More than 900 responses were collected during the period of survey, and the EFA found two main categories of perceived advocates for COVID-19 use: behavioural disobedience $(55.9 \%)$ and no advocates
(86.5\%). Behavioural disobedience was expressed as fear of stigmatisation (62.9\%), inability to seek help (59.3\%) and holding and mixing (44.8\%). Low compliance with precautions was indicated by financial problems (92.4\%), overpopulation $(87.6 \%$ ), wearing mask on 
faces $(81.6 \%)$ and sanitation $(79.1 \%)$. Barriers identified were classed in three different factors: two misconceptions, misbelief $(31.6 \%)$ and fake guarantees $(32.9 \%)$, and single rightous perceived, compliance with right measures (17.1\%).[14,15,16] Misbelief about avoiding infection from viruses were associated with beliefs about religiosity and the effect of certain foods, fever, conventional medicine and liquor consumption, varied from $15.1 \%$ to $54.7 \%$. Misperceptions included perceptions of not living in areas where COVID-19 is prevalent $(36.9 \%)$ and no locally reported cases (29.5\%); COVID-19 was most commonly cited in relation to prevention methods (62.6\%), disease behaviour and management $(59.5 \%)$, proper knowledge (including the answers to unanswered questions, like the virus's origin) with a great need for information (2.4\%). Health professionals were identified as the group at greatest risk (83.3\%). Children, adolescents and young adults were found to be at low to moderate risk $(45.1 \%$ $62.2 \%$ ) of infection with COVID-19. Community, local authority and provision to communicate showed huge differences in misbelief, fake guarantees and need for knowledge $(\mathrm{p}<0.05) .[11-13]$

\section{DISCUSSION:}

This online survey provided an insight into the perceptions of communities across the country about the factors, risk labelling and information needs that contribute to, or prevent the spread of COVID-19 in Ethiopia. The perceived factors were classified based on compliance with rules of conduct, inadequacy of surrounding factors, misbeliefs, wrong safety, inclusion of mainstream preventions and study on disease precaution, manners and management, involving solutions of many problems about the birth, communicability and prevention of coronaviruses. Every factor has been addressed step by step, as indicated below.

This survey has led us to an understanding of how the people or the common man perceives the major problems of the world and its effects in daily routine and having many different views such which may be false and many a times referred as a myth and having no understanding about it leading to many other cases of fake news and with fact checking a source spreads these false facts and its consequences may be hazardous.

The factors perceived as inhibiting the communicability fell into different categories: wrong guarantee (32.9\%), misbelief $(31.6 \%)$ and participation in main preventions $(17.1 \%)$. A pair of factors in this trio was falsely inferred as barriers and therefore labelled as myths and false reassurances. False assurance represented the impression of invincibility and was characterised by people believing they lived outside the COVID-19 risk zone. In this study, myths included religion, diet, living in a warm climate, traditional medicine, and alcohol consumption in protection against COVID-19 (15.1\%). The WHO myth buster summarises most of the misconceptions presented in this study and shows that they are common worldwide in the context of pandemics [14].

The study found significant regional differences in myths, false sense of security and need for prevention information. It has close ties with most of the regions and cities of Ethiopia, that could then cause exaggerated communication of disease in other regions, as it is a myth. Furthermore, the information showed difference in division in the misbelief, with significantly more clustering in the larger cities than in the counties and districts. Therefore, much attention needs to be given to better understanding and clarification of the myths. In terms of information gaps, the need for prevention information is greater 
in southern regions, zonal towns and district towns. Vaccination is now an important factor that community need to know of, but it is heavily influenced by conspiracy theories, as shown in a study conducted in Pakistan.

The above evidence on perceptions justifies the fact that community preparedness and response to the spread of the virus cannot withstand the rapid increase in the number of infections, and suggests that communication and involvement with those most at risk is effective. There were several factors to back up this belief. First, the rate of containment (involvement in prevention activities) of correctly identified viruses was low, at $17.1 \%$. Second, there was a high level of non-compliance and inadequacy of necessary sources related to struggles to control COVID-19. Third, misbelief and wrong certainties prevailed.[15-19].Articles on Covid 19 rumours and fake news reflected on many issues [21-24]. A number of other interesting studies related to actual community and health effects are available[25-27].

\section{CONCLUSIONS:}

This survey has led to acknowledgement of how this pandemic was perceived by the eyes of the community and their misbelief of this disease which had inferred them a far less preparedness for a situation like this and what should have been done to prevent an outbreak of this calibre, but now have contributed to the study of such misbelief and false assurance that which could hamper the preventability of a disease and its management.

This accumulation of this society's inference points supporting and preventing the extent of spread of COVID-19, identifying the groups susceptible, and resource needs gives some important facts that which is used to manage the spread of this lethal disease. Many of the misbelief and fake acceptance was inferred which was falsely identified as the inhibitors of these rapid progression of this unknown disease of a virus such as the inferred religion of the mass, known after effects of the selected grocery and other items such as spices and fruits and various vegetables which are supposed to be good for our immunity and help in a better system in our body to fight against this virus, staying in this very warm climate surrounding, standard pharmaceuticals, consuming liquor, and regions away from the risky or susceptible areas. Zonal and city's differentiation in dynamic of false belief, fake news, and resource understanding leaps indicate the dire need for variable and region framing of information and work up of that advances the society's right to the fight against this disease. Misbelief and fake acceptance must be urgently addressed in a more appropriate and decrease COVID-19 chances to prevent it, accordingly. regional and townships had more knowledge requirement. Approach to various types of information sources that which give a proper knowledge which is needed to full fill facts needed rather to just mere various number of such sources which have no meaning to it and just lead to various myths and no help to the public.

People's common information needs include how to protect themselves from the virus, isolation and quarantine, and what measures people with symptoms should take to maintain their health. The WHO considers health workers, the elderly and people with underlying diseases to be at risk, but in a country like Ethiopia, where young people live, it can be difficult to define young people and adolescents as being at medium or low risk in countries with a high population density, such as Ethiopia. In countries with large adolescent populations, such as Ethiopia, special attention may need to be given to adolescents to ensure that they are actively involved in prevention efforts. 
Risk communication and community participation efforts should 1) address regional and urban differences in myths and false certainties, 2) continue to seek beliefs that may contribute to or inhibit the spread of the virus, 3) respond to information needs, 4) develop local initiatives that increase community participation in combating the virus by maintaining and promoting adherence to standard precautions, and 5) respond to the growing volume of information they receive for the falsehood against COVID19 , which should be properly regulated with the appropriate system.

\section{REFERENCES:}

[1] World Health Organization. Statement on the second meeting of the International Health Regulations (2005) Emergency Committee regarding the outbreak of novel coronavirus (2019-nCoV). Geneva, Switzerland. 2020.

[2] Nishiura $H$. The Extent of Transmission of Novel Coronavirus in Wuhan, China, 2020. J. Clin. Med. 2020, 9,330.

[3] Paules C.I.; Marston H.D.; Fauci A.S. Coronavirus Infections-More than Just the Common Cold. JAMA 2020. 10.1001/jama.2020.0757

[CrossRef].

[4] Cao JL, Tu WJ, Hu XR, \& Liu Q. (2020). Clinical Features and Shortterm Outcomes of 102 Patients with Corona Virus Disease 2019 in Wuhan, China. Clinical Infectious Diseases, 10.1093/cid/ciaa243/5814897

[5] Cao JL, Hu XR, Tu WJ.,\& Liu Q. (2020). Clinical Features and Shortterm Outcomes of 18 Patients with Corona Virus Disease 2019 in the Intensive Care Unit. Intensive Care Medicine, 10.1007/s00134-02005987-7.
[6] Wang C, Horby PW, Hayden FG, et al. A novel coronavirus outbreak of global health concern. Lancet 2020;395(10223):470-73. 10.1016/S0140-6736(20)30185-9 [published Online First: 2020/01/28]

[7] Hawryluck L. SARS control and psychological e_ects of quarantine, Toronto, Canada. Emerg. Infect. Dis. 2004, 10, 1206-1212. [CrossRef] [PubMed]. 10.3201/eid1007.030703

[8] Chen N. Epidemiological and clinical characteristics of 99 cases of 2019 novel coronavirus pneumonia in Wuhan, China: A descriptive study. Lancet 2020, 395, 507-513. [CrossRef]. 10.1016/S01406736(20)30211-7

[9] Holshue M.L. First Case of 2019 Novel Coronavirus in the United States. N. Engl. J. Med. 2020.

[10] World Health Organization (WHO). Risk Communication and Community Engagement (RCCE) Action Plan Guidance COVID-19 Preparedness and Response. 16 March 2020. Available at: https://www.who.int/docs/defaultsource/coronaviruse/covid19-rcceguidance-final-brand.pdf

[11] World Health Organization (WHO) and UNICEF. The social stigma associated with coronavirus disease (COVID-19). Last updated on 24 February 2020. Available at: https://www.unicef.org/documents/so cial-stigma-associated-coronavirusdisease-covid-19

[12] Rothe C. Transmission of 2019nCoV Infection from an Asymptomatic Contact in Germany. N. Engl. J. Med. 2020. [CrossRef]. 10.1056/NEJMc2001468

[13] 18. Ryu S.; Chun B.C. Korean Society of Epidemiology-nCov, an interim review of the epidemiological characteristics of 2019 novel coronavirus. Epidemiol. Health 2020， 42， e2020006 
[CrossRef] 10.4178/epih.e2020006

[14] Huang C. Clinical features of patients infected with 2019 novel coronavirus in Wuhan, China. Lancet 2020, 395, 497-506. [CrossRef]. 10.1016/S0140-6736(20)30183-5

[15] Chan JF, Yuan S, Kok KH, et al. A familial cluster of pneumonia associated with the 2019 novel coronavirus indicating person-toperson transmission: a study of a family cluster. Lancet 2020;395(10223):514-23. 10.1016/S0140-6736(20)30154-9

[16] Cao Z. Estimating the elective reproduction number of 2019-nCoV in China. medRxiv 2020.

[17] Li Q. Early Transmission Dynamics in Wuhan, China, of Novel Coronavirus-Infected Pneumonia. N. Engl. J. Med. 2020. [CrossRef]. 10.1056/NEJMoa2001316

[18] World Health Organization (WHO). Coronavirus disease (COVID-19) advice for the public: Myth busters. Last updated, 27 April 2020. Available at: https://www.who.int/emergencies/dis eases/novel-coronavirus2019/advice-for-public/myth-busters

[19] Ethiopia population (2020)Wordometer. Available at: https://www.worldometers.info/worl $\underline{\mathrm{d}-}$

population/ethiopiapopulation/\#: :te xt $=$ Ethiopia\%202020\%20population\%2 0is\%20estimated, of $\% 20$ the $\% 20$ total\%20world\%20pop ulation.

[20] Khatib, M.N., S. Gaidhane, M. Khatib, M. Ahmed, A. Gaidhane, and Z.Q. Syed. "SARS-CoV and SARSCoV-2: Similar Viruses with Different Trajectories." WutanHuatanJisuanJishu 16, no. 5 (2020): 544-48.
[21] Mandwar, S., S. Dharampuria, G. Nimbulkar, K.G. Chhabra, and A. Reche. "Misconceptions and Myths about COVID-19." International Journal of Research in Pharmaceutical Sciences 11, no. Special Issue 1 (2020): 1319-22. https://doi.org/10.26452/ijrps.v11iSP L1.3630.

[22] Masurkar, D., and P. Jaiswal. "Myths about COVID-19." International Journal of Research in Pharmaceutical Sciences 11, no. Special Issue 1 (2020): 907-12. https://doi.org/10.26452/ijrps.v11iSP L1.3124.

[23] Srivastava, K.C., D. Shrivastava, K.G. Chhabra, W. Naqvi, and A. Sahu. "Facade of Media and Social Media during Covid-19: A Review." International Journal of Research in Pharmaceutical Sciences 11, no. Special Issue 1 (2020): 142-49. https://doi.org/10.26452/ijrps.v11iSP L1.2288.

[24] Toshida, T., and C. Jagruti. "COVID-19 - Rumours and Facts in Media." International Journal of Research in Pharmaceutical Sciences 11, no. Special Issue 1 (2020): 17174.

https://doi.org/10.26452/ijrps.v11iSP L1.2344.

[25] Mahapatra, J., and P. Nikhade. "Covid-19: A Pandemic Situation." International Journal of Research in Pharmaceutical Sciences 11, no. Special Issue 1 (2020): 787-95. https://doi.org/10.26452/ijrps.v11iSP L1.3084.

[26] Mehta, J., S. Baliga, N. Thosar, N. Rathi, S. Jain, R. Srivastava, and R. Waykar. "Management of Pandemic Crisis: COVID-19." International Journal of Research in Pharmaceutical Sciences 11, no. Special Issue 1 (2020): 885-91. https://doi.org/10.26452/ijrps.v11iSP L1.3110. 
[27] Balsara, K., and D. Shukla. "Stepping up Detection, Response, Preparedness and Readiness Measures for 'Covid-19'-a Pandemic." International Journal of Research in Pharmaceutical Sciences 11, no. Special Issue 1 (2020): 104247.

https://doi.org/10.26452/ijrps.v11iSP L1.3442. 